\title{
Phase of Division and Budding of Human Erythrocytes in Serum-Free Cultures and Further Refinement Mass Production Plan by Amphiphilic Surfactants
}

\section{Gen Niimi*}

Joint Research Laboratory, Fujita Health University, Toyoake, Aichi, Japan

The presence of erythropoietin receptors and erythropoiesis on erythrocytes is disputable. However, the specific binding of erythropoietin to mammalian erythrocytes was reported [1-6] as well as gene expressions [7-9]. Recently, we proposed a growth-division and fission process involving adult human erythrocytes [10]. More recently, Andes-Koback and Keating [11] and Terasawa et al. [12] reported the budding and division of primitive anucleate model cells. Here, we show the division and budding of human erythrocytes following the delayed addition of erythropoietin in serum-free cultures and further refinement mass production plan by amphiphilic surfactants [13-15].

Normal adult human erythrocytes were isolated from the blood of the authors collected in EDTA- $\mathrm{Na}_{2}$ tubes by venipuncture. Erythrocytes were separated by centrifugation at $400 \mathrm{~g}$ for 10 minutes. A total of $50 \mu \mathrm{l}$ of packed red blood cells was suspended in $10 \mathrm{ml}$ of DMEM/F12, and then cultured in disposable conical tubes, then examined on days 0,7 , $14,21,28,35$ and 42 of culture at room temperature.

On days $0,7,14,21,28,35$ and 42 of culture, each red blood cell suspension $(50 \mu \mathrm{l})$ was individually lifted from the primary cultures, and then treated with an equal or double the volume of DMEM/F12 supplemented with 5 units $/ \mathrm{ml}$ of human erythropoietin in plastic microtubes at room temperature. Each days of culture, $0.5 \mu \mathrm{l}$ of the red blood cell/5U erythropoietin mixture was dropped on glass cover slips and the cover-slips were inverted over a hole in micro slide glasses, sealed with chemical glue (hanging-drop preparations), and observed by light microscopy (Figure 1).

Further refinement mass production plan by amphiphilic surfactants (boldface).

- Manmalian blood, $400 \mathrm{~g}, 10 \mathrm{~min}$

- Packed red cells, $50 \mu \mathrm{l}+\mathrm{DMEM} / \mathrm{F} 12,10 \mathrm{ml}$. Culture (1 day 5 weeks)
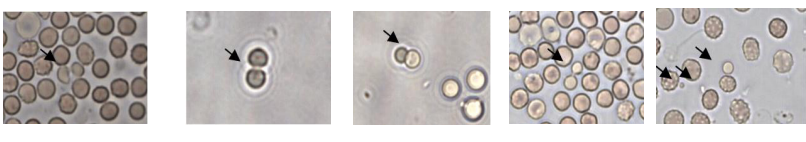

b

Division and fission

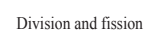

Division and fissio

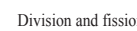

Multiple budding

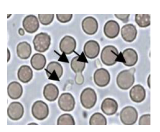

f

Multiple budding

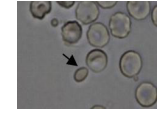

g

Budding and fission

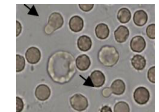

$\mathrm{h}$

Multiple budding

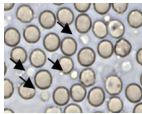

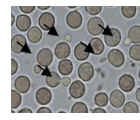

Multiple budding
Figure 1: Light microscopic photographs of various phases of division and budding of human erythrocytes (arrows) Objective lens $\times 60$.
- Red blood cell suspension, $50 \mu \mathrm{l}\left(3.0 \times 10^{8} \quad\right.$ cells $\left./ \mathrm{ml}\right)+$ amphiphilic surfactants $(0.05 \%$ poloxamer $188[13,14]$, or 0.05 $\%$ polysorbate 80 , or $50 \mu \mathrm{M}$ sodium dodecyl sulfate [15], etc.), $10 \sim 50 \mu \mathrm{l}$ mixture (30 120 $\mathrm{min})$

- Red blood cell suspension, $50 \mu \mathrm{l}+$ erythropoietin (5 units), 50 $\mu \mathrm{l}$ Culture $(1 \sim 8 \mathrm{~h})$

- Hanging drop culture, Red blood cell and erythropoietin suspension, $0.5 \mu$ l. ( $2 \mathrm{~h} \sim 3$ days $)$

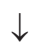

- Fission $[10-12,15](10 \mathrm{~min} \sim 6 \mathrm{~h})$

\section{References}

1. Baciu I, Ivanof L, Pavel T (1980) Effect of erythropoietin on ribose consumption in rat erythrocytes. Clujul Medical 53: 47-54.

2. Baciu I, Ivanof $L$ (1983) Distribution of erythropoietin (Ep) between plasma and erythrocytes. Clujul Medical 56: 349-353.

3. Baciu I, Ivanof L (1983) Erythropoietin interaction with the mature red cell membrane. Ann N Y Acad Sci 414: 66-72.

4. Baciu I, Ivanof L, Pavel T, Marina C, Zirbo M, et al. (1985) Erythropoietin binding to the red cell membranes. Physiologie 22: 227-231.

5. Myssina S, Huber SM, Birka C, Lang PA, Lang KS, et al. (2003) Inhibition of erythrocyte cation channels by erythropoietin. J Am Soc Nephrol 14: 2750 2757.

6. Mihov D, Vogel J, Gassmann M, Bogdanova A (2009) Erythropoietin activates nitric oxide synthase in murine erythrocytes. Am J Physiol Cell Physiol 297 C378-388.

7. Rathjen T, Nicol C, McConkey G, Dalmay T (2006) Analysis of short RNAs in the malaria parasite and its red blood cell host. FEBS Lett 580: 5185-5188.

8. Masaki S, Ohtsuka R, Abe Y, Muta K, Umemura T (2007) Expression patterns of microRNAs 155 and 451 during normal human erythropoiesis. Biochem Biophys Res Commun 364: 509-514.

9. Kabanova S, Kleinbongard P, Volkmer J, Andrée B, Kelm M, et al. (2009) Gene expression analysis of human red blood cells. Int J Med Sci 6: 156-159.

*Corresponding author: Gen Niimi, Joint Research Laboratory, Fujita Health University, Toyoake, Aichi, 470-1192, Japan, E-mail: g-niimi@fujita-hu.ac.jp

Received March 22, 2013; Accepted April 05, 2013; Published April 07, 2013

Citation: Niimi G (2013) Phase of Division and Budding of Human Erythrocytes in Serum-Free Cultures and Further Refinement Mass Production Plan by Amphiphilic Surfactants. Human Genet Embryol 3: 104. doi:10.4172/2161-0436.1000104

Copyright: (c) 2013 Niimi G. This is an open-access article distributed under the terms of the Creative Commons Attribution License, which permits unrestricted use, distribution, and reproduction in any medium, provided the original author and source are credited. 
Citation: Niimi G (2013) Phase of Division and Budding of Human Erythrocytes in Serum-Free Cultures and Further Refinement Mass Production Plan by Amphiphilic Surfactants. Human Genet Embryol 3: 104. doi:10.4172/2161-0436.1000104

Page 2 of 2

10. Niimi G, Ohashi K, Ide T, Pereda J (2009) Budding and direct division of adult human erythrocytes in serum-free cultures. Okajimas Folia Anat Jpn 86: 73-77

11. Andes-Koback M, Keating CD (2011) Complete budding and asymmetric division of primitive model cells to produce daughter vesicles with different interior and membrane compositions. J Am Chem Soc 133: 9545-9555.

12. Terasawa H, Nishimura K, Suzuki H, Matsuura T, Yomo T (2012) Coupling of the fusion and budding of giant phospholipid vesicles containing macromolecules. Proc Natl Acad Sci U S A 109: 5942-5947.
13. Lemieux P, Guérin N, Paradis G, Proulx R, Chistyakova L, et al. (2000) A combination of poloxamers increases gene expression of plasmid DNA in skeletal muscle. Gene Ther 7: 986-991.

14. Baek EJ, Kim HS, Kim JH, Kim NJ, Kim HO (2009) Stroma-free mass production of clinical-grade red blood cells (RBCs) by using poloxamer 188 as an RBC survival enhancer. Transfusion 49: 2285-2295.

15. Inaoka Y, Yamazaki M (2007) Vesicle fission of giant unilamellar vesicles of liquid-ordered-phase membranes induced by amphiphiles with a single long hydrocarbon chain. Langmuir 23: 720-728. 